\title{
Application of Tariff System in Thermal Energy Supply to Public Buildings in E Function of Development of the City of Kraljevo
}

\author{
mr Jovan Nesovic ${ }^{1, *}$, Dragan Arsenijevic ${ }^{1}$, Nikola Filipovic ${ }^{1}$ \\ PEC "Toplana” Kraljevo
}

\begin{abstract}
Rational consumption of thermal energy to heat public buildings is an important factor in the functioning of local governments for two reasons, as follows: reduction of fixed costs (rational public finances management) and reduction of energy consumption by which we rationally consume energy resources and therefore protect the environment. Application of supplied thermal energy billing according to consumption for business spaces started in early 2014 in Kraljevo. This paper provides an analysis of thermal energy consumption, with the supporting financial analysis, in several public buildings, and a proposal of measures to reduce the consumption in the next period, i.e. to use thermal energy more rationally.
\end{abstract}

Key words: thermal energy, consumption, cost, energy efficiency

\section{INTRODUCTION}

When talking about local government units are talking about complex systems that are not isolated, but are found in a complex interaction with their environment, which among other subjects is made up of the economy and other local governments. We must also note the trend of cities and municipalities struggling for better investment market positioning in order to be more recognizable than competitive local communities. Today, advanced local governments are recognized by fast and good administration, short and transparent procedures, good communal, social and economic infrastructure, socially and environmentally responsible policies. Energy management, i.e. rational and sustainable energy management is not at a satisfactory level in Serbia nor in the city of Kraljevo. One of the directions cities and municipalities can choose to follow for better recognition and competitiveness in attracting investments is their promotion and strengthening in leading an energy responsible politics, which means rational and sustainable energy management.

Increase of energy efficiency in production, distribution and consumption of any form of energy by the end users of services is one of the basic priorities defined in the Energy Development Strategy of the Republic of Serbia. Energy issues are becoming more current day by day, and energy strategies are gaining more significance and are an essential segment of any country's politics. Energy price increasing trend, exhaustion of fossil fuel reserves, emission of gasses that create the greenhouse effect and impact to the world climate and the environment condition in general, supply problems, are some of the factors that speak in favor of these claims. In the next period, the local governments will be facing the problem of stable supply of thermal energy to the citizens and the business sector. Apart from that, there will be additional pressure on the budgets which cover the costs of using thermal energy to heat public buildings financed by a local government of another state institution. For that reason, some of the general goals of local governments in the area of energy policy are:

$>$ Providing optimal and secure energy supply,

$>$ Increasing comfort in public buildings,

$>$ Reducing energy consumption, and thus reducing costs covered by the local budget,

$>$ Improving the level of services provided by the local governments to their citizens,

$>$ Reducing negative effects to the environment.

Rational use of thermal energy may save significant funds in the local government budget through the reduction of fixed costs (public buildings heating costs). Therefore, in the next period, special attention must be paid to energy efficiency of public buildings (insulation quality, joinery quality, reduction of space overheating, etc.) and funds must be allocated for reconstruction of buildings where required in order to improve the energy efficiency. The funds invested return very fast (in a couple of years) through the reduction of heating costs, which is a significant budget saving in the perspective. In addition, it is very important in the next period to replace the boilers in public buildings with individual boilers that use expensive energy sources (heating oil, fuel oil) with boilers that use cheaper energy sources (wood chips, pellet). This may also make significant savings in the budget, and it is also important from the aspect of environmental protection.

On the basis of data gathered on the measured amount of thermal energy supplied for the heating of public buildings, this paper provides detailed analysis of energy efficiency and the costs related to the heating of the observed buildings connected to the remote heating system. The paper represents a good basis for the production of a feasibility study for the reconstruction of public buildings aiming to increase energy efficiency, i.e. reduce costs of heating the public buildings. 


\section{CONSUMPTION OF THERMAL ENERGY DURING THE HEATING SEASON}

Average consumption of thermal energy for heating is a very important parameter in the evaluation of energy efficiency of certain buildings. On the one hand, it depends on the average outdoor temperature during the heating period, and on the quality of buildings being heated and how the users of such space rationally use the thermal energy on the other hand. If average outdoor temperature during the heating period is high, the average consumption of thermal energy will be less, and vice versa. Buildings with good insulation consume less thermal energy. Also, if users of the space behaved rationally (saved thermal energy), consumption would be less. Rational behavior means that inflow of thermal energy should be reduced when space is not used by adjusting the device to lower scale value (room temperature can be set to less than $20^{\circ} \mathrm{C}$ ), and that space should not be cooled by opening the window but by reducing the inflow of thermal energy, etc.
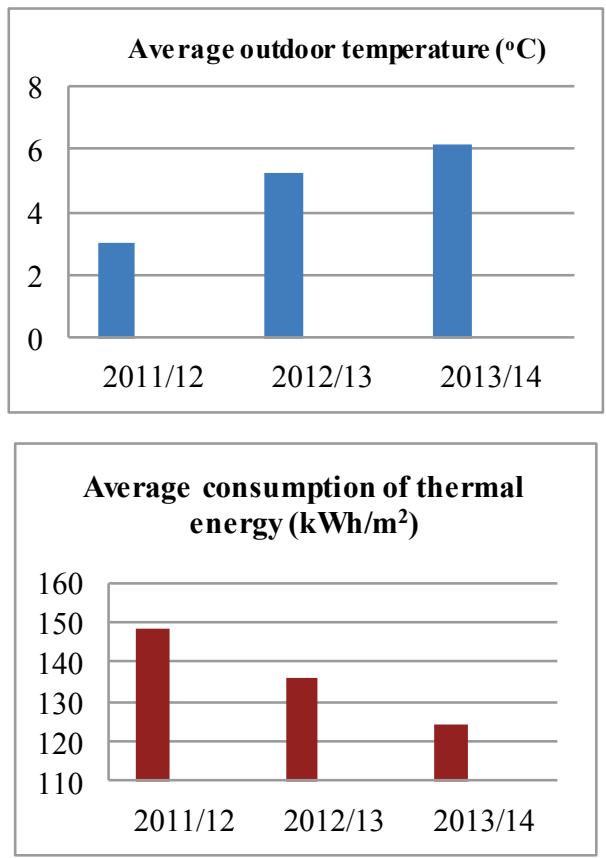

Figure 1. Presentation of average outdoor temperatures and average consumption of thermal energy to heat the space in the previous three heating seasons

Figure 1 shows average temperatures and average consumption of thermal energy for business space heating in the city of Kraljevo. It can be concluded that from the aspect of thermal energy consumption, the most favorable was the heating season 2013/2014 because the average outdoor temperature in the heating season was the highest $\left(6.18^{\circ} \mathrm{C}\right)$. Average consumption of thermal energy for space heating in the heating season 2013/14 was $121 \mathrm{kWh} / \mathrm{m}^{2}$ [2]. To analyze the energy efficiency of public buildings in the city of Kraljevo, we have selected four public buildings as follows: Medical School buildings, City Administration building, the Higher Court building and the building of the Ministry of Interior.
Measuring the delivered thermal energy to heat the facilities shall be done in thermal substations. They represent a connection of the remote heating system with the consumers' inner installations (public building) and their task is to provide the building with thermal energy. Also, they are equipped with all necessary equipment for automated operation than needs to provide building heating comfort and independency in terms of heating intensity according to own needs. Today, substations with indirect connection are mostly used, implying the existence of heat exchanger used to exchange thermal energy between the primer and secondary waters. In addition, the exchanger separates the circulation circles of the remote heating system and building's inner installations. Advantage of such substations is that the pressure in the building's installations is independent and less than the pressure in heating lines. Also, there is no mixing of water from the building's inner installations with water from the remote heating system. Figure 2 shows a heating substation device located in the City Administration building, and a similar device is located in other public buildings analyzed herein.

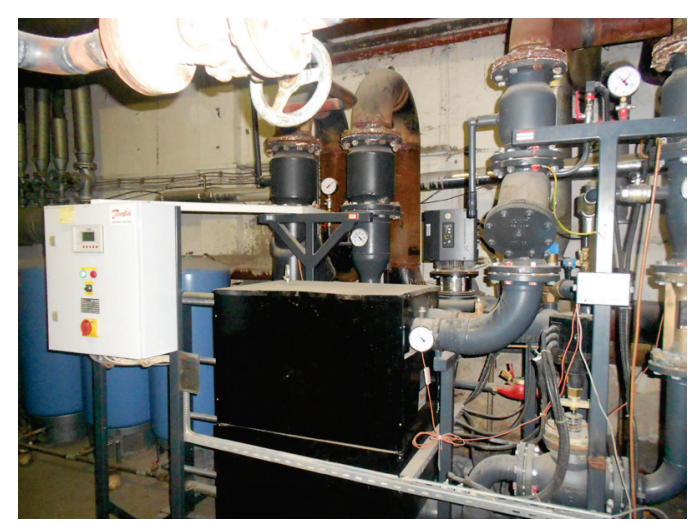

Figure 2. Heating substation in the City Administration building

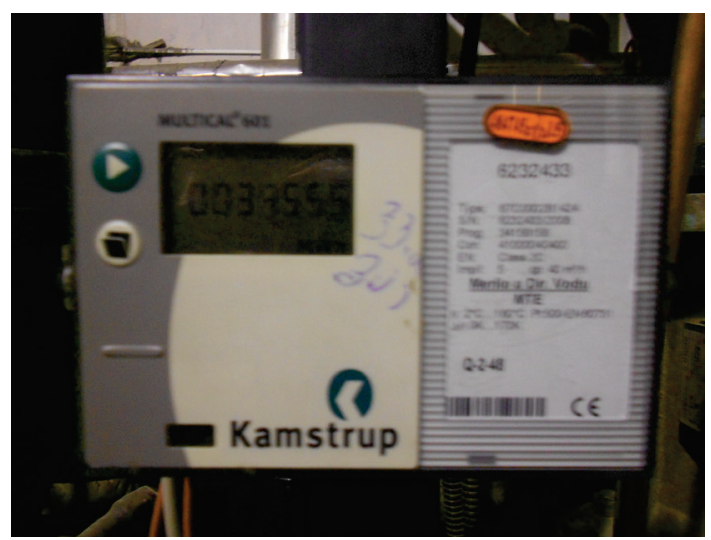

Figure 3. Delivered thermal energy gauge on the substation in the City Administration building

Gauge is a device that registers the amount of delivered thermal energy (Figure 3). It is a compact measuring device with fully electronic measuring of thermal energy 
consumed by the users that is calculated based on the measuring of mass flow, temperature at the outlet and temperature at the return of the primary.

The diagram below (Figure 4) shows the average consumption of thermal energy in four selected buildings in the months (January, February, March, April) when the billing for building heating was according to the thermal energy consumption.

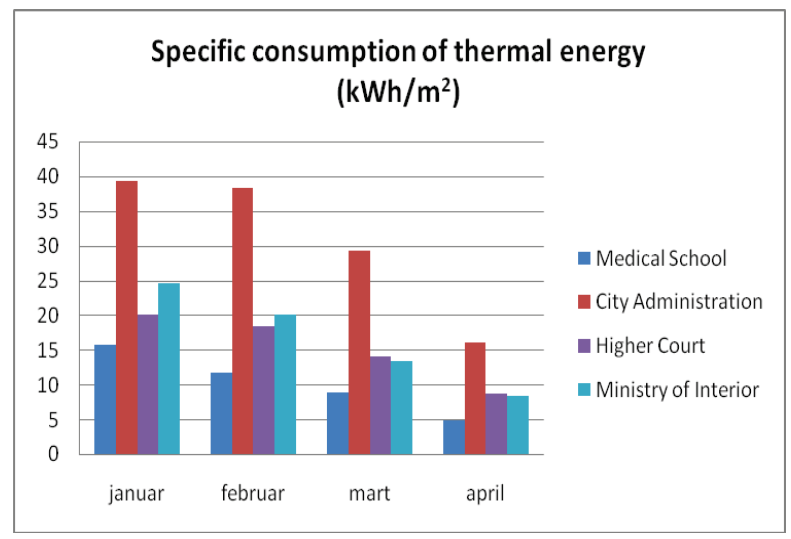

Figure 4. Diagram of thermal energy consumption to heat the public buildings selected

It can be seen from the diagram that the building of the City Administration has high consumption and that it is very energy inefficient. The buildings of the Ministry of Interior and the Higher Court are at the limit of average energy efficiency (they correspond to the average consumption of all buildings in the city), while the Medical School building, where energy efficiency measures have been implemented, has low thermal energy consumption during the heating season (in the heating season 2013/2014 consumption amounted to 78 $\left.\mathrm{kWh} / \mathrm{m}^{2}\right)$.

\section{ECONOMIC INDICATORS OF AAPLYING THE TARIFF SYSTEM TO PUBLIC BUILDINGS}

\section{a) Forming the price of supplied thermal energy}

Total bill for the users consists of two parts (1) - flat and variable part.

$C=C_{F}+C_{V}$

The flat part of the bill is determined in a way that the heated surface of public buildings $\left(\mathrm{m}^{2}\right)$ is multiplied by unit flat rate $\left(\mathrm{RSD} / \mathrm{m}^{2}\right)$, which is the same for all business and public buildings. These funds shall cover the depreciation costs, expenses related to investment and current maintenance, salaries and other personal revenues, and other non-production costs. This part of the bill shall be paid during the heating season for business space.

The variable part of the bill is determined in a way that the average amount of thermal energy $(\mathrm{kWh})$ is multiplied with the unit price for the variable part (RSD/
$\mathrm{kWh}$ ), which is the same for all business and public buildings. The variable cost refers to the price of fuel, the amount of average electrical energy necessary in the production and distribution of thermal energy and to the consumed amount of water and its chemical preparation. This part of the bill shall be paid during the heating season. Unit prices for the flat and variable parts shall be determined by the decision of the City of Kraljevo Assembly.

\section{b) Public buildings heating costs}

Economic indicators of tariff system application have been prepared on the basis of thermal energy prices as follows:

- payment per meter square of heated surface (current manner of billing) price is 250.5 $\mathrm{RSD} / \mathrm{m}^{2}$,

- payment per consumption - flat part is 90 $\mathrm{RSD} / \mathrm{m}^{2}$, and the variable part is 7.91 $\mathrm{RSD} / \mathrm{kWh}$ [3].

Table 1. Basic data about the buildings and consumption of thermal energy

\begin{tabular}{|c|c|c|c|c|c|}
\hline \multirow[t]{2}{*}{ Building } & \multirow{2}{*}{$\begin{array}{l}\text { Building } \\
\text { heated } \\
\text { surface } \\
\left(\mathrm{m}^{2}\right)\end{array}$} & \multicolumn{4}{|c|}{$\begin{array}{l}\text { Thermal energy consumption }(\mathrm{kWh}) \text { per } \\
\text { months }\end{array}$} \\
\hline & & January & February & March & April \\
\hline $\begin{array}{l}\text { Medical } \\
\text { School } \\
\text { buildings }\end{array}$ & 3650 & 57,248 & 42,499 & 32,627 & 17,927 \\
\hline $\begin{array}{l}\text { City } \\
\text { Administration } \\
\text { building }\end{array}$ & 4513 & 177,500 & 172,900 & 131,800 & 72,600 \\
\hline $\begin{array}{l}\text { Higher Court } \\
\text { building }\end{array}$ & 1696 & 34,086 & 31,313 & 23,711 & 14,788 \\
\hline $\begin{array}{l}\text { Ministry of } \\
\text { Interior } \\
\text { building }\end{array}$ & 3750 & 92,050 & 74,970 & 49,980 & 31,670 \\
\hline
\end{tabular}

On the basis of data from the Table 1 and the prices of supplied thermal energy, we may calculate the total cost for both systems (payment per heated area and payment per consumed thermal energy), which are shown in Figure 5.

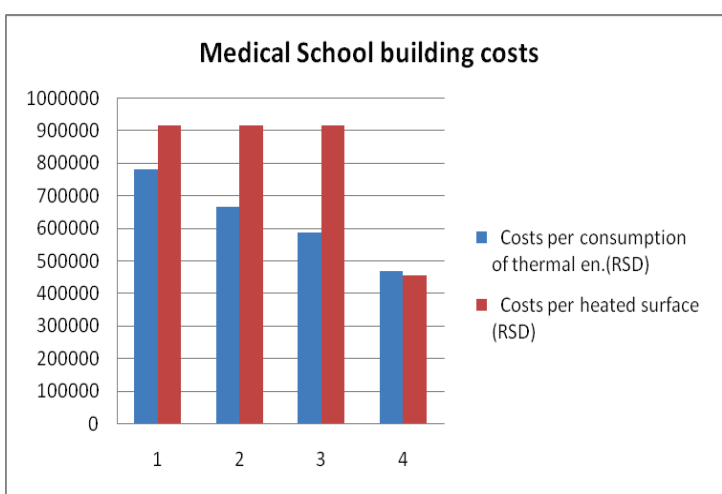



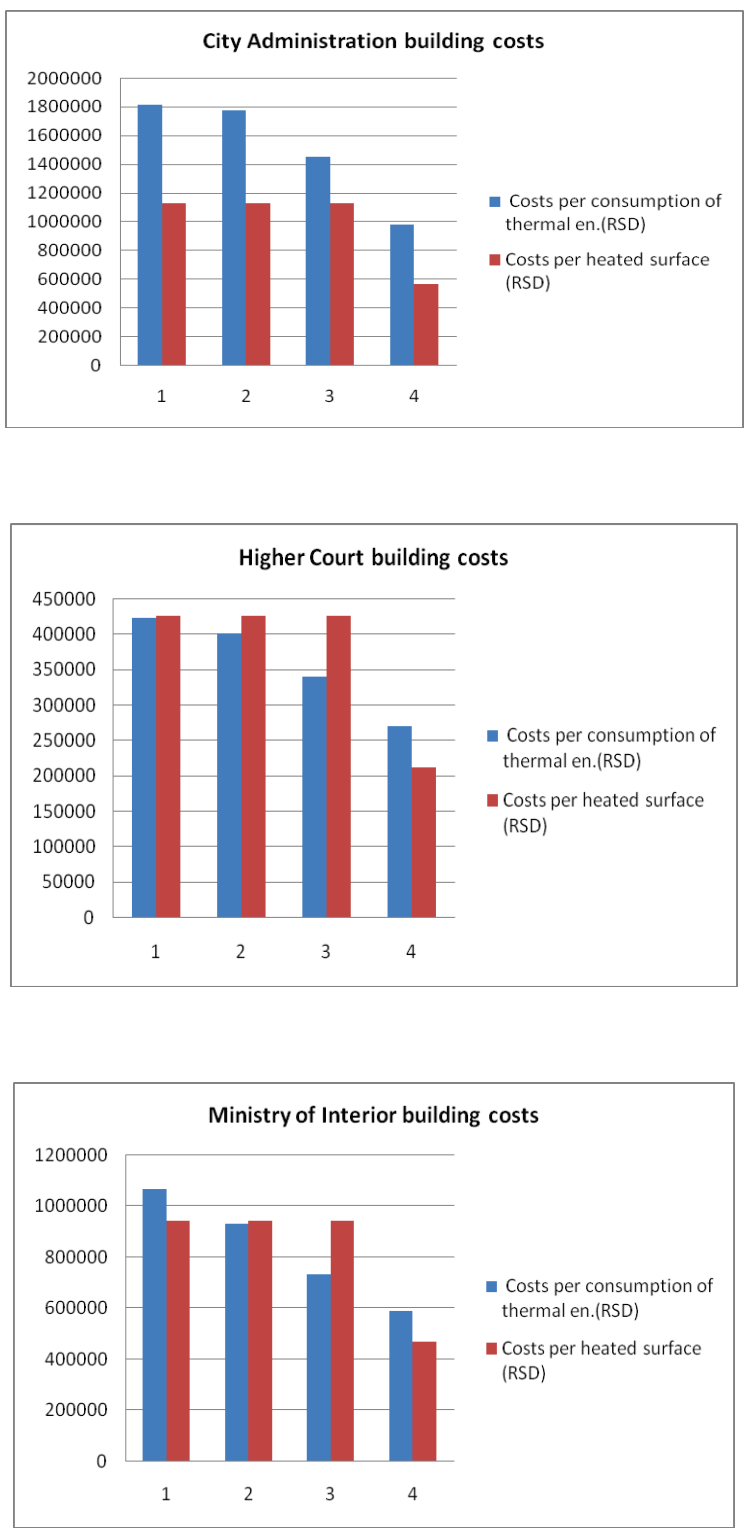

Figure 5. Graphic display of heating costs of buildings according to calculation of supplied thermal energy (blue bars) and according to heated surface (red bars)

Based on the analysis above it can be concluded that heating costs of the Medical School building are significantly reduced $(21.8 \%)$, while the heating costs of the City Administration building have drastically increased $(51.95 \%)$. As far as the buildings of the Higher Court and the Ministry of Interior are concerned, costs are almost the same as before.

Detailed review of these costs with increase/decrease percentages is given in Table 2.
Table 2. Comparative analysis of total cost for the observed buildings in the period January-April 2014

\begin{tabular}{|l|l|l|l|l|}
\hline Building & $\begin{array}{l}\text { Cost per } \\
\text { heated } \\
\text { surface } \\
\text { (RSD) }\end{array}$ & $\begin{array}{l}\text { Cost per } \\
\text { thermal } \\
\text { energy } \\
\text { consumption } \\
\text { (RSD) }\end{array}$ & $\begin{array}{l}\text { Difference } \\
\text { (RSD) }\end{array}$ & $\begin{array}{l}\text { Increase/decre } \\
\text { ase percentage } \\
\text { (\%) }\end{array}$ \\
\hline $\begin{array}{l}\text { Medical } \\
\text { School } \\
\text { buildings }\end{array}$ & $3,200,138$ & $2,502,881$ & $-697,257$ & $\mathbf{- 2 1 . 8}$ \\
\hline $\begin{array}{l}\text { City } \\
\text { Administr } \\
\text { ation } \\
\text { building }\end{array}$ & $3,957,650$ & $6,013,508$ & $2,055,858$ & $\mathbf{5 1 . 9 5}$ \\
\hline $\begin{array}{l}\text { Higher } \\
\text { Court } \\
\text { building }\end{array}$ & $1,486,968$ & $1,432,393$ & 54,575 & $\mathbf{0 . 0 4}$ \\
\hline $\begin{array}{l}\text { Ministry } \\
\text { of Interior } \\
\text { building }\end{array}$ & $3,287,813$ & $3,316,980$ & $-29,167$ & $\mathbf{- 0 . 0 1}$ \\
\hline
\end{tabular}

The Medical School building was constructed several years ago according to all modern construction rules and it has good energy efficiency, while the City Administration building was constructed fifty years ago; it has large glass areas, poor wall and roof insulation and it is very energy inefficient. For this reason, it is important to plan its reconstruction in the next period. Buildings of the Higher Court and the Ministry of Interior are old buildings, however, they were both reconstructed (including insulation) some time ago, and the energy efficiency thereof has significantly increased.

\section{MEASURES TO REDUCE THE HEATING COSTS OF PUBLIC BUILDINGS}

Smaller consumption of thermal energy creates the conditions to pay smaller bills, which means that all measures should be taken to eliminate the energy loss to the maximum, i.e. to use the thermal energy rationally in public buildings. In this regard, it is required to do the following:

$>$ Install thermostatic valves on radiators to control the consumption of thermal energy. Consumption may be regulated by installing the regulation equipment in the building substation.

$>$ Check the quality of joinery. Clearances on windows and doors case great heat loss and it is required to eliminate them somehow.

$>$ Check building wall insulation. Good insulation reduces the loss of thermal energy.

$>$ Check the insulation of piping in the basement and stairs. If not insulated or if insulation is poor, it is required to repair them.

$>$ Check the temperature. Optimal temperature in heated rooms is app. $21{ }^{\circ} \mathrm{C}$, and it is less in hallways. Every degree more consumes app. 5\% more energy.

$>$ Lower the temperature in business spaces when absent, as well as in the spaces not used.

$>$ Rooms should not be aired for more than 10 minutes. This way we preserve the thermal energy accumulated in the walls and furniture. 
It is not recommended to regulate room temperature by opening the window.

$>$ Covered and obscured radiator in business spaces is isolated and has not real output.

\section{CONCLUSION}

Energy efficiency at the local level is one of the priorities for the development of local governments. Certain buildings (example of the City Administration building in this paper) are very energy inefficient and they use large amount of thermal energy for heating. This causes significant increase of costs, increased fuel consumption and environmental pollution. For the purpose of sustainable use of resources, it is required in the next period to plan in the strategic and operation development plans at the local level significant funds for the improvement of energy efficiency of buildings. With clear plans and projects, funds for this purpose may be secured from donor sources, structural funds, state institutions. Local governments thus became more competitive for investments and the investors, which is the most important assignment of every local government.

\section{REFERENCES}

[1] „Racionalno korišćenje energije u funkciji razvoja lokalnih zajednica - zbirka dobre prakse" PALGO centar, Beograd 2010.

[2] „Pregled specifične potrošnje toplotne energije grejna sezona 2013/14“, JEP „Toplana“ Kraljevo, 2014.

[3] „Program poslovanja sa finansijskim planom za 2014.“, JEP „,Toplana“ Kraljevo, 2014.

4] Jelena Bojović „Lokalni ekonomski razvoj priručnik za praktičare“",THE URBANE INSTITUTE, Beograd 2010.

[5] Zakon o lokalnoj samoupravi, Službeni glasnik RS, 129/2007.

[6] Zakon o efikasnom korišćenju energije, službeni glasnik RS, 25/2013.

[7] „Tehnika grejanja - katalog proizvoda 2013“ Danfoss Beograd, 2013. 